\title{
Geochemical and Sm-Nd isotopic study of titanite from granitoid rocks of the eastern Dharwar craton, southern India
}

\author{
R ANAND ${ }^{1,2, *}$ and S BALAKRISHNAN ${ }^{1}$ \\ ${ }^{1}$ Department of Earth Sciences, Pondicherry University, Puducherry 605 014, India. \\ ${ }^{2}$ PPOD Division, Geological Survey of India, Bangalore 560 070, India. \\ *e-mail: anandrajagopal78@gmail.com
}

\begin{abstract}
Titanite occurs as an accessory phase in a variety of igneous rocks, and is known to concentrate geologically important elements such as U, Th, rare earth element (REE), Y and Nb. The differences in the abundances of the REEs contained in titanite from granitoid rocks could reflect its response to changes in petrogenetic variables such as temperature of crystallization, pressure, composition, etc. Widespread migmatization in the granodiorite gneisses occurring to the east of Kolar and Ramagiri schist belts of the eastern Dharwar craton resulted in the enrichment of the REEs in titanite relative to their respective host rocks. A compositional influence on the partitioning of REEs between titanite and the host rock/magma is also noticed. The relative enrichment of REEs in titanite from quartz monzodiorite is lower than that found in the granodioritic gneiss. Depletion of REE and HFSE (high field-strength elements) abundances in granitic magmas that have equilibrated with titanite during fractional crystallization or partial melting has been modelled. As little as $1 \%$ of titanite present in residual phases during partial melting or in residual melts during fractional crystallization can significantly lower the abundances of trace elements such as $\mathrm{Nb}, \mathrm{Y}, \mathrm{Zr}$ and REE which implies the significance of this accessory mineral as a controlling factor in trace element distribution in granitoid rocks. Sm-Nd isotope studies on titanite, hornblende and whole rock yield isochron ages comparable to the precise $\mathrm{U}-\mathrm{Pb}$ titanite ages, invoking the usefulness of $\mathrm{Sm}-\mathrm{Nd}$ isochron ages involving minerals like titanite.
\end{abstract}

\section{Introduction}

Titanite, zircon, allanite, apatite and rutile are common accessory minerals in granitoid rocks. These minerals are known to concentrate trace elements like $\mathrm{Nb}, \mathrm{U}, \mathrm{Th}, \mathrm{Hf}$ and lanthanide group elements, also called as rare earth elements or REE (Gromet and Silver 1983; Ward et al 1992; Bea 1996). In granitoid rocks allanite can contain most of the light REE and control their distribution (Gromet and Silver 1983; Sawka et al 1984; Bea 1996; Poitrasson et al 2002) but the modal abun- dance of titanite in granitoid rocks is usually much greater than that of allanite (Gromet and Silver 1983). Titanite may therefore contain large amounts of REE and HFSE (high field strength elements), and moderate amounts of $\mathrm{U}$ in granitoid rocks (Ward et al 1992; Bea 1996; Frost et al 2000; Poitrasson et al 2002; Tiepolo et al 2002; Prowatke and Klemme 2005, 2006). Titanite is known to contain total rare earth element content ranging from $\sim 0.7$ to $\sim 3.5$ wt $\%$ (Green and Pearson 1986). Gromet and Silver (1983) showed that more than $80-90 \%$ of the total REE

Keywords. Titanite; Kolar; Ramagiri; Dharwar craton; rare earth elements; Sm-Nd isotope dating. 
abundances of granodiorites reside in titanite and allanite. The decrease in overall REE abundances in rocks representing residual melts can be attributed to the presence of titanite or apatite in the cumulate assemblage formed from monzodiorite or granodiorite parent magmas (Basir and Balakrishnan 1999; Stevenson et al 1999). Thus titanite has the potential to explain the distribution of REE among the petrogenetically related phases of granitoid rocks (Gromet and Silver 1983; Basir and Balakrishnan 1999). Titanite also plays an important role while modelling abundances of trace elements such as Nb, Ta, Y, U and Zr in felsic rocks (Fleischer and Altschuler 1969; Green and Pearson 1987; Ryerson and Watson 1987; Tiepolo et al 2002; Seifert 2005).

Gromet and Silver (1983) reported that the whole rock-normalized pattern of titanite in a granodiorite from eastern Peninsular ranges batholith, southern California was enriched in heavy and middle REE relative to light REE. Stern and Hanson (1991) showed that the whole rock-normalized REE pattern of titanite was sub-parallel to that of the whole rock. Basir and Balakrishnan (1999) showed both convex-up and sub-parallel patterns relative to the whole rock from the titanites of granitoid rocks around the Hutti-Maski schist belt, in the eastern Dharwar craton.

Titanite also crystallizes during metamorphism or migmatization (Franz and Spear 1985; Tucker et al 1987; Deer et al 1992; Gieré 1992; Tiepolo et al 2002). When a rock with titanite is subjected to upper amphibolite facies or higher grade of metamorphism, the change in $\mathrm{P}-\mathrm{T}$ conditions can bring about changes in the trace element abundances of titanite as the partition coefficients of trace elements, especially REE are known to be altered by variations in temperature and/or pressure (Green and Pearson 1986). It is therefore of interest to understand the difference in REE abundance between igneous and metamorphic titanites. A comprehensive study of trace element (including REE) geochemistry of titanites is essential to determine the relative enrichment of trace elements such as $\mathrm{Nb}$ and REE (a) in compositionally different granitoid rocks like quartz monzodiorites, granodiorites and granites, and (b) in titanites formed or equilibrated during migmatization of granodiorites.

Titanite has been widely used as a geochronometer owing to its common occurrence and elevated $\mathrm{U}$ and Th contents (Pan et al 1993; Corfu and Stone 1998; Frost et al 2000; Storey et al 2006). Titanite is also useful for dating using $\mathrm{Sm}-\mathrm{Nd}$ isotope system because it incorporates significant amount of REE. Titanite have distinct $\mathrm{Sm} / \mathrm{Nd}$ ratio compared to major minerals that constitute granitoid rocks such as plagioclase, hornblende or biotite (Taylor and McLennan 1985; Li 1994). These minerals can be expected to have similar closure temperatures for the $\mathrm{Sm}-\mathrm{Nd}$ system as they occur adjacent to each other and is reasonable to consider that the $\mathrm{Sm}-\mathrm{Nd}$ equilibrated between them (Futa 1981). Therefore, $\mathrm{Sm} / \mathrm{Nd}$ isotope dating using titanite and other minerals may be considered as an alternative to $\mathrm{U}-\mathrm{Pb}$ isotope dating. $\mathrm{Sm}$ and $\mathrm{Nd}$ are relatively less mobile in various geological conditions as compared to $\mathrm{Rb}, \mathrm{Sr}$ and $\mathrm{Pb}$ (DePaolo and Wasserburg 1979; Rollinson 1993). Thus Sm-Nd isotope study on titanites, hornblende or biotite crystallized at the same time along with the whole rock can provide meaningful age information. Two samples, a granodiorite and a quartz monzodiorite surrounding Kolar and Ramagiri schist belts respectively, whose ages were precisely determined by $\mathrm{U}-\mathrm{Pb}$ titanite and zircon geochronology (Krogstad et al 1991; Balakrishnan et al 1999), were chosen for this exercise.

\section{Geology of the study area}

The Dharwar craton (figure 1a) is divided into an eastern and a western domain with reference to N-S sinistral shear zone that forms the eastern boundary of the Chitradurga schist belt (Chadwick et al 1992). The eastern Dharwar craton is interspersed with several schist belts such as the Kolar, Ramagiri and Hutti schist belts, which are surrounded by late Archean granitoid rocks (Swami Nath et al 1976; Nutman et al 1996; Chadwick et al 2000). The schist belts of the eastern Dharwar craton are made up of metamorphosed basaltic rocks with subordinate chemical sediments. Unlike their western counterparts, clastic sediments such as argillite and greywacke are negligible in the schist belts of the eastern Dharwar craton. A clear indication of a gneissic basement for the supracrustal rocks of the Dharwar Group as encountered in the western Dharwar craton (Chadwick et al 1981a, 1981b, 1985a, 1985b) is but lacking in the east. There is a general increase in the grade of metamorphism from north to south in the Dharwar craton, proceeding from lower greenschist facies to the upper amphibolite and granulite facies (Pichamuthu 1965; Raase et al 1986). Granitoid rocks (orthogneisses and less deformed intrusive rocks) are common in and around the schist belts and occupy ca. $70 \%$ of the area of the craton. The general geology of the granitoid rocks surrounding the Kolar and Ramagiri schist belts is discussed below.

\subsection{Kolar schist belt}

The Kolar schist belt predominantly consists of metavolcanic rocks and banded ferruginous 

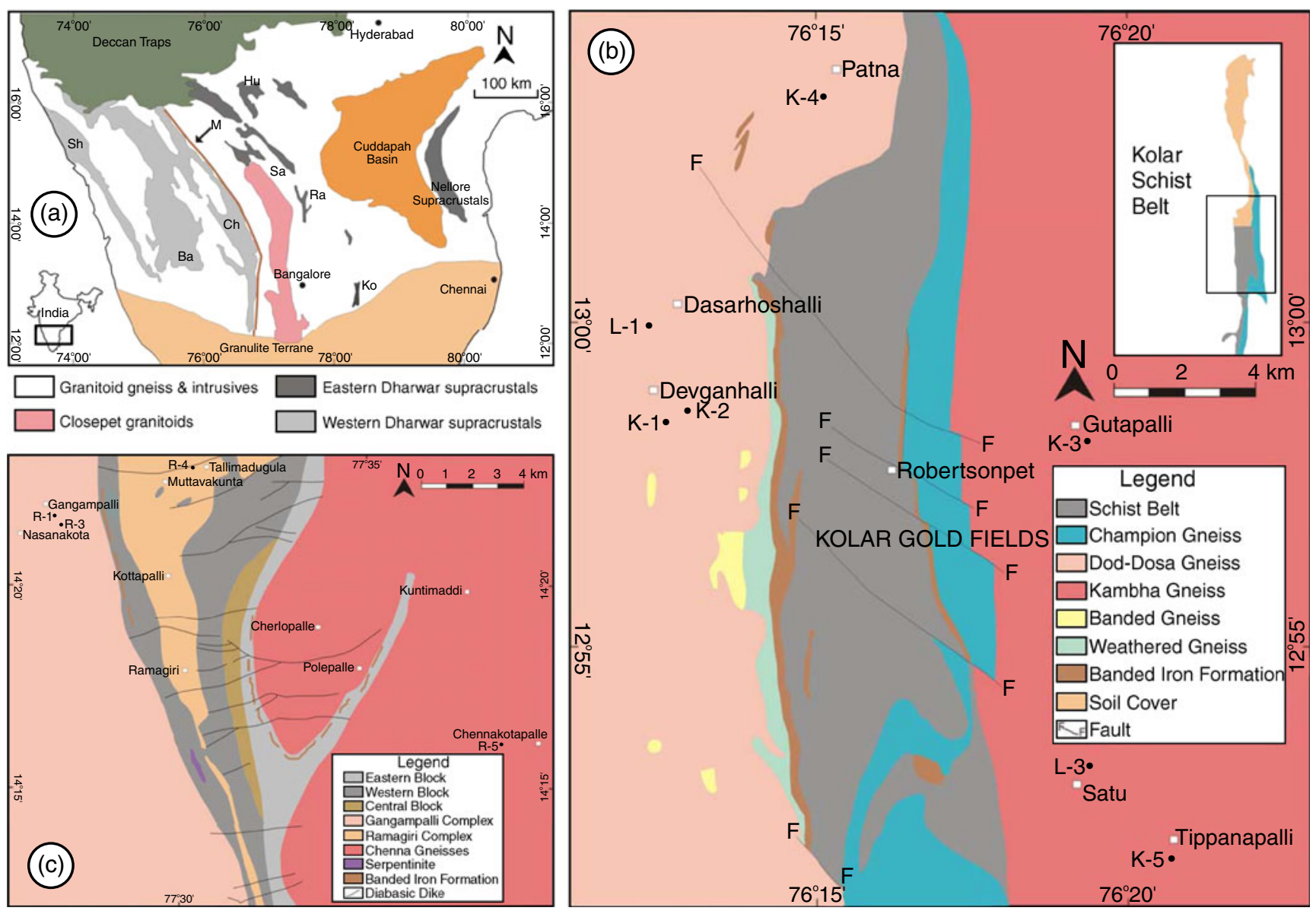

Figure 1. (a) Geological map of the Dharwar craton, southern India (modified after Chadwick et al 1996). The eastern and western parts of the Dharwar craton are considered to have had distinct evolutionary histories. Ba: Bababudan, Sh: Shimoga, Ch: Chitradurga, Hu: Hutti, Ko: Kolar, Ra: Ramagiri and Sa: Sandur schist belts. M: Mylonitised zone on the eastern margin of the Chitradurga schist belt. (b) Geological map of the central part of the Kolar schist belt and the surrounding granitoid rocks Balakrishnan and Rajamani (1987). Sample locations marked as L-1, K-1 and K-2 are from the western Dod-Dosa granodiorite gneisses. Sample locations L-3, K-3 and K-5 are from the eastern Kambha gneisses. Location K-4 represents the Patna granitoid. (c) Geological map of the Ramagiri schist belt and the surrounding granitoid rocks (modified from Ghosh et al 1970). Sample locations R-1 and R-3 are from the western Gangam complex. Sample location R-4 is from the central Ramagiri complex. Sample location R-5 is from the eastern Chenna gneisses.

quartzite (BFQ), and is surrounded on all sides by granitoid rocks (figure $1 \mathrm{~b}$ ). The granitoid rocks outcropping to the west of the schist belt have been differentiated based on the bulk mineralogy into quartz monzodioritic Dod gneisses and granodioritic Dosa gneisses (Balakrishnan and Rajamani 1987). Both these gneisses are made up of abundant quartz, K-feldspar, biotite, hornblende, and accessory titanite and zircon. Mafic enclaves and quartz and quartzo-feldspathic veins are common. To the northwest of the Kolar schist belt, a foliated granodiorite pluton referred to as the Patna granitoid crops out, which contains abundant quartz, K-feldspar, plagioclase, biotite, hornblende, epidote and titanite. To the east of the belt migmatitic gneisses of granodiorite composition known as the Kambha gneisses crop out. These gneisses are made up of quartz, plagioclase, biotite, minor hornblende, abundant accessory titanite and rare zircon. All the granitoid rock types mentioned above were sampled and processed for titanite separation in this study (figure $1 \mathrm{~b}$ ).

The $\mathrm{U}-\mathrm{Pb}$ titanite and zircon ages determined on the granitoid rocks of the Kolar belt by Krogstad et al $(1989,1991)$ and in the Ramagiri areas by Balakrishnan et al (1999), are shown in table 1. In the Kolar area, the Patna granitoid has yielded identical titanite and zircon $\mathrm{U}-\mathrm{Pb}$ ages of $2552 \pm 1$ and $2551 \pm 2.5$ Ma respectively, whereas, in the Dod gneiss the zircon age of $2631 \pm 6.5 \mathrm{Ma}$ is about 80 million years older than the titanite $\mathrm{U}-\mathrm{Pb}$ age of $2551 \pm 2$ Ma. Jayananda et al (2000) have ${ }^{207} \mathrm{~Pb} /{ }^{206} \mathrm{~Pb}$ plateau ages of $2534-2552 \mathrm{Ma}$ for zircons from a quartz monzonite occurring from the western margin of the Kolar schist belt. A granodiorite gneiss from the Kambha gneisses to the east of the Kolar schist belt gave a zircon $\mathrm{U}-\mathrm{Pb}$ age of $2532 \pm 3 \mathrm{Ma}$ which is approximately 11 million 
Table 1. The U-Pb titanite and zircon isotope ages of granitoid rocks surrounding the Kolar and Ramagiri schist belts, Eastern Dharwar craton.

\begin{tabular}{|c|c|c|c|c|}
\hline Locality & Unit & Rock type & $\begin{array}{l}\mathrm{U}-\mathrm{Pb} \text { age of } \\
\text { titanite }(\mathrm{Ma})\end{array}$ & $\begin{array}{l}\mathrm{U}-\mathrm{Pb} \text { age of } \\
\text { zircon }(\mathrm{Ma})\end{array}$ \\
\hline \multicolumn{5}{|c|}{ Kolar area (Krogstad et al 1991) } \\
\hline Eastern gneisses & Kambha gneiss & Granodiorite gneiss & $\begin{array}{l}2521 \pm 2 \\
2517 \pm 2 \\
2501 \pm 8\end{array}$ & $\begin{array}{l}2532 \pm 3 \\
\quad-\end{array}$ \\
\hline Western granitoids & $\begin{array}{l}\text { Dod gneiss } \\
\text { Dosa gneiss } \\
\text { Patna granite }\end{array}$ & $\begin{array}{l}\text { Quartz diorite gneiss } \\
\text { Granodiorite gneiss } \\
\text { Granodiorite }\end{array}$ & $\begin{array}{c}2551 \pm 2 \\
- \\
2552 \pm 1\end{array}$ & $\begin{array}{l}2631 \pm 6.5 \\
2610 \pm 10 \\
2551 \pm 2.5\end{array}$ \\
\hline \multicolumn{5}{|c|}{ Ramagiri area (Balakrishnan et al 1999) } \\
\hline $\begin{array}{l}\text { Eastern gneisses } \\
\text { Central granitoids }\end{array}$ & $\begin{array}{l}\text { Chenna gneiss } \\
\text { Ramagiri complex }\end{array}$ & $\begin{array}{l}\text { Granodiorite gneiss } \\
\text { Granodiorite } \\
\text { Quartz diorite }\end{array}$ & $\begin{array}{l}2545 \pm 1 \\
2614 \pm 4 \\
2595 \pm 1\end{array}$ & $\begin{array}{c}>2650 \pm 7 \\
2613 \pm 6 \\
-\end{array}$ \\
\hline Western granitoids & Gangam complex & $\begin{array}{l}\text { Granodiorite } \\
\text { Quartz monzodiorite }\end{array}$ & $\begin{array}{l}2516 \pm 3 \\
2510 \pm 2\end{array}$ & $\begin{array}{c}2528 \pm 1 \\
-\end{array}$ \\
\hline
\end{tabular}

years older than the titanite age of $2521 \pm 2$ Ma. Due to the absence of any cross-cutting relationship of the younger granitoid rocks with the schist belt, the presence of sheared rocks at the margin of the schist belt and dichotomy of cooling history of granitoid rocks occurring on either side of the schist belt, Krogstad et al (1989) suggested that the two gneissic terranes occurring on either side of the schist belt were juxtaposed after $2517 \pm 2 \mathrm{Ma}$, the titanite age for the Kambha gneisses, but before $2420 \pm 12 \mathrm{Ma}$ which is the ${ }^{40} \mathrm{Ar}-{ }^{39} \mathrm{Ar}$ muscovite plateau age from sheared gneisses occurring close to the western contact between the western granitoid rocks and the Kolar schist belt (Krogstad et al. 1989).

\subsection{Ramagiri schist belt}

The Ramagiri schist belt (figure 1c) is trident shaped (Balakrishnan et al 1999) and consists of three arms of metavolcanic rocks. Granitoid rocks referred to as the Gangam complex crop out on the western part of the Ramagiri schist belt, the Chenna gneisses to the east of the belt and the Ramagiri complex separating the central and western arms (figure 1c). The Chenna gneisses are chiefly composed of plagioclase, quartz, biotite and hornblende and are well-foliated and granodioritic, and in some places migmatized. Quartz monzodiorite predominates in the Gangam complex and the Ramagiri complex consists of quartz diorite, granodiorite and granite in the decreasing order of abundance. The Gangam quartz monzodiorite has abundant titanite along with plagioclase, quartz and mafic minerals such as biotite and hornblende. The granodiorite shows a porphyritic texture with abundant quartz, plagioclase and biotite, accessory titanite and rare zircon.
A granodiorite from the central Ramagiri complex gave identical titanite and zircon $\mathrm{U}-\mathrm{Pb}$ ages of $2614 \pm 4$ and $2613 \pm 6 \mathrm{Ma}$, respectively (Balakrishnan et al 1999), while zircon from the western Gangam complex granodiorite gave an age of $2528 \pm 1 \mathrm{Ma}$, approximately 12 million years older than the titanite age of $2516 \pm 3$ Ma. Zircon from the eastern Chenna gneisses gave a $\mathrm{U}-\mathrm{Pb}$ age of $2650 \pm 7 \mathrm{Ma}$ (Balakrishnan et al 1999) which is interpreted as the age of the igneous protolith. This age is at least 100 million years older than the titanite age of $2545 \pm 1 \mathrm{Ma}$ from the same rock, which is interpreted as the time of migmatization of the Chenna gneisses (Balakrishnan et al 1999).

The significance of titanite ages lies in its lower closure temperature $\left(>650^{\circ} \mathrm{C}\right.$, Scott and St-Onge 1995; Zhang and Schärer 1996; Pidgeon et al 1996) for $\mathrm{U}-\mathrm{Pb}$ isotope system than zircon $\left(>900^{\circ} \mathrm{C}\right.$, Mezger 1990; Pidgeon et al 1996) and its response to slower rates of cooling of the igneous protolith and events such as high temperature $\left(>650^{\circ} \mathrm{C}\right)$ metamorphism and metasomatism.

Based on the combined $\mathrm{U}-\mathrm{Pb}$ zircon and titanite age data from the Kolar and Ramagiri areas three distinct types of cooling histories for the granitoid rocks could be identified. They are:

- Identical zircon and titanite ages indicating a faster rate of cooling either due to intrusion of granitoid magma at shallow crustal levels or as small bodies;

- Titanite ages are younger by $\sim 10-20$ million years than zircon ages, due to slower rate of cooling as a result of intrusion of magma at deeper crust;

- Titanite ages are younger by $>80$ million years than zircon ages, indicating that these granitoid rocks were affected by post-crystallization 
thermal events in which the temperature exceeded the titanite closure temperature for the $\mathrm{U}-\mathrm{Pb}$ isotope system.

\section{Sampling and analytical methods}

In order to understand the REE distribution between titanite and whole rock, granitoid rocks with three different cooling histories described in the previous section were sampled from the Kolar and Ramagiri areas. Two samples from the Dosa granodiorites (L-1 and K-2), one from the Dod quartz diorites (K-1) and one granodiorite (K-4) from the Patna area were collected west of the Kolar schist belt and one sample each from Satu (L-3), Tippanapalli (K-5) and Gutapalli (K-3) areas were collected east of the schist belt (figure 1b). The samples from the Ramagiri belt include one quartz monzodiorite (R-1) and one granodiorite (R-3) from the western Gangam complex, one quartz diorite (R-4) from the central Ramagiri complex and one sample from the eastern Chenna gneisses (R-5, figure 1c).

The titanite separated from Dod and Dosa granitoid rocks show pale brown to dark brown pleochroism under the microscope. The titanites from
Patna granite are clear crystals that range from anhedral to euhedral (figure 2a). The titanite from the Kambha gneisses occurring east of the schist belt are clear euhedral and even as large as $1 \mathrm{~cm}$ in some samples. Some of the crystals show twinning (figure $2 \mathrm{~b}$ ).

The titanite from the Gangam and the Ramagiri complexes are subhedral to euhedral, clear and show minor alteration at some places (figure 2c). The titanite from the migmatized Chenna gneisses are anhedral, showing resorbed rims under the microscope and are associated with opaque minerals (figure 2d).

BSE and CL images of selected titanite grains from Kolar and Ramagiri granitoid rocks were imaged (figure 3) using scanning electron microscope (Hitachi S3400). The operation conditions were $22 \mathrm{kV}$ accelerating voltage and $50-60 \mathrm{~mA}$ probe current. The titanite grains are clear in the images but for tiny inclusions of possibly apatite and zircon.

\subsection{Major and trace element analysis}

For the analysis of major elements on titanite, thin and polished sections of the granitoid rocks from Kolar and Ramagiri area were made. These
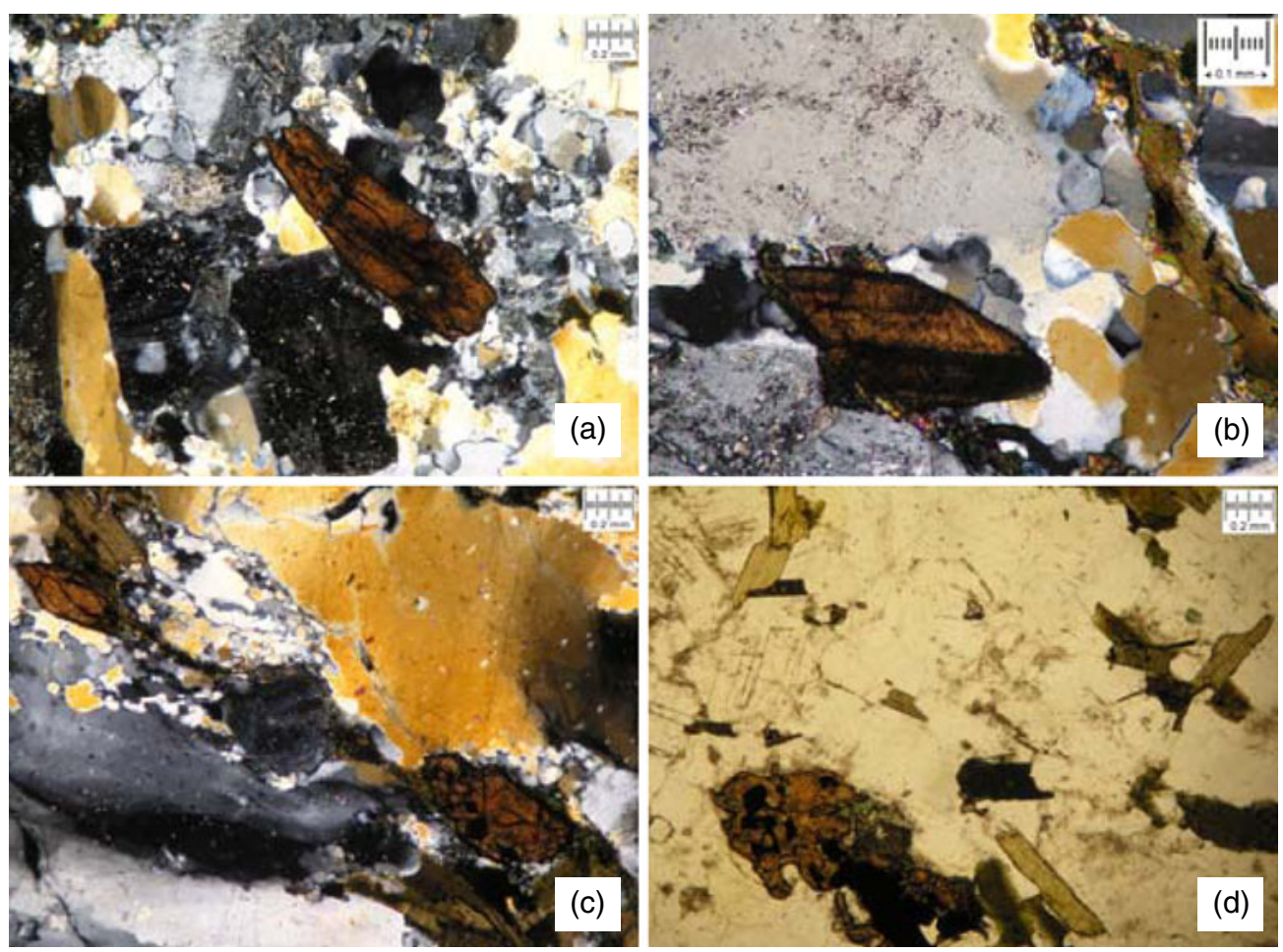

Figure 2. Photomicrographs of (a) Patna granitoid (K-4) showing quartz, feldspar and a millimetre long crystal of titanite. (b) Kambha gneiss from Tippanapalli (K-5) showing quartz, altered feldspar and a twinned euhedral crystal of titanite. (c) Gangam granodiorite (R-3) showing quartz, feldspar, biotite and subhedral to euhedral grains of titanite. (d) Migmatized Chenna gneiss (R-5) showing quartz, feldspar, biotite and an anhedral grain of titanite with resorbed rims found associated with opaque minerals. 

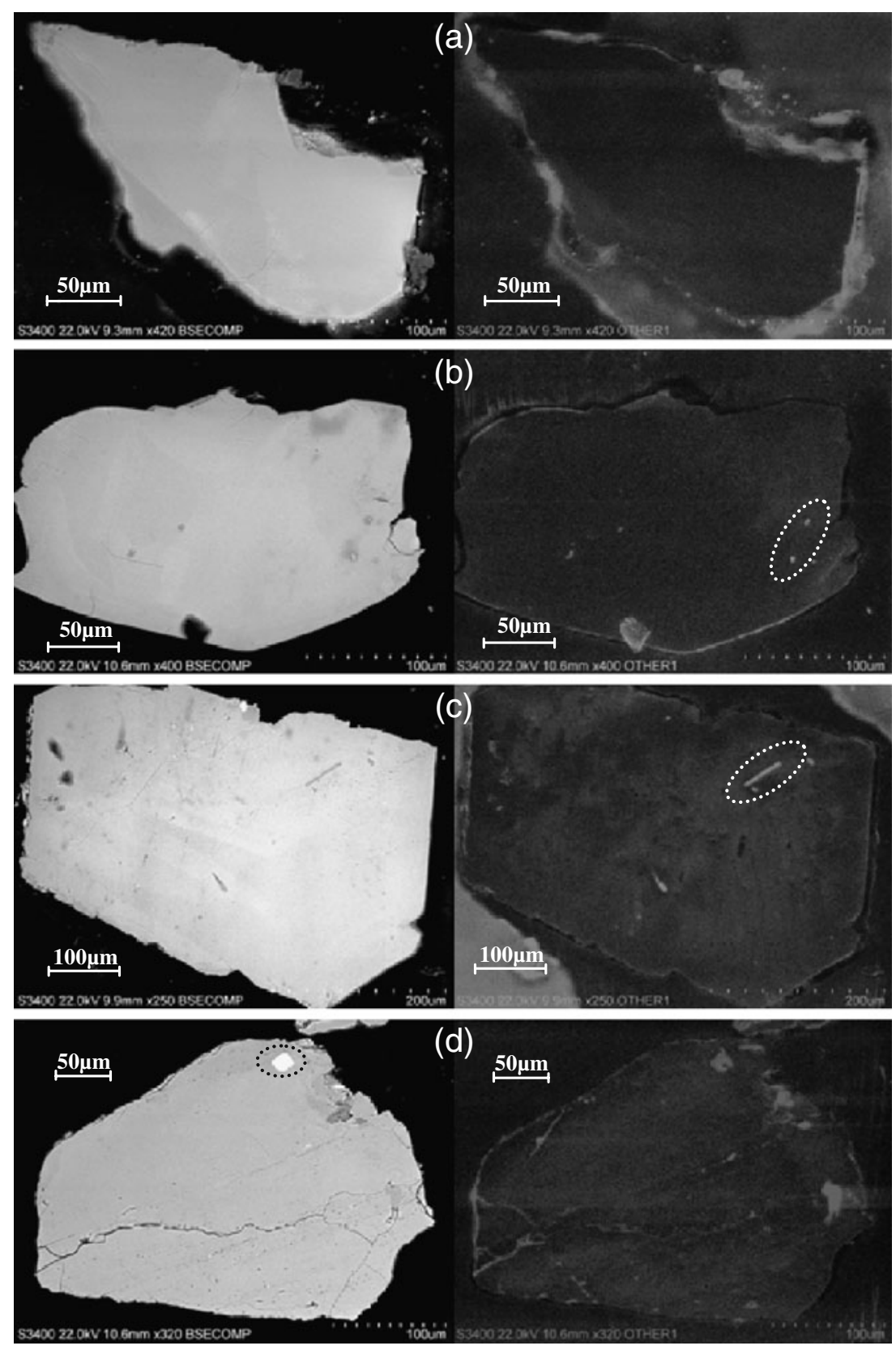

Figure 3. BSE and CL images of selected titanite grains from Kolar and Ramagiri granitoid rocks. Grain (a) is from Dod quartz diorite $(\mathrm{K}-1),(\mathbf{b})$ is from Dosa granodiorite (K-2), and (c) is from Patna granite (K-4) and )(d) is from Gangam quartz monzodiorite (R-1). These grains are devoid of zoning but contain tiny mineral inclusions of possibly apatite and/or zircon marked as dotted ellipses.

were coated with carbon and used for the analysis of major elements using an Electron Probe Micro Analyser (EPMA-model $\mathrm{S} \times 50$ Cameca) at the Department of Geology, Mysore University. The EPMA was calibrated with mineral standards such as biotite, apatite, anorthite, diopside, ilmenite and rutile. Suitable points on the titanite mineral grains were chosen and analyzed for the major elements. The results of the analysis are given in table 2 .

For trace element analysis, about $5 \mathrm{~kg}$ of rock fragments were crushed to -80 mesh size and titanite was concentrated using heavy liquids and Frantz ${ }^{\circledR}$ Magnetic Separator. Approximately $0.05 \mathrm{~g}$ of titanite was taken and digested with $1 \mathrm{ml}$ of $\mathrm{HF}$ and $0.5 \mathrm{ml}$ of $\mathrm{HNO}_{3}$. Additional $\mathrm{HNO}_{3}$ was added to remove all traces of $\mathrm{HF}$ if present. The REEs were separated and enriched using cation exchange resin columns, involving several steps of elution with $\sim 2 \mathrm{~N}$ and $6 \mathrm{~N}^{-H_{N}}$ and $\mathrm{HCl}$.

For the determination of $\mathrm{Nb}, \mathrm{Ta}, \mathrm{Y}, \mathrm{Sc}, \mathrm{Ba}, \mathrm{Sr}$ and $\mathrm{Pb}, 50 \mathrm{mg}$ of titanite from each sample were reacted with $\mathrm{HF}+\mathrm{HNO}_{3}+\mathrm{HCl}$ for five hours and 
the digested sample was dried and dissolved in $1 \mathrm{~N}$ $\mathrm{HNO}_{3}$ for analysis.

The REE elutes were analysed using ICP-AES (Jobin Yvon - Ultima2) at the National Facility for Geochemical Research in the School of Environmental Sciences, Jawaharlal Nehru University, New Delhi. By routinely analysing internal rock standards VM-9 and 90-57 along with the titanites and the standards AMH and DGH supplied by the Wadia Institute of Himalayan Geology, Dehradun
(Saini et al 1998) as unknowns, the accuracy of the analysis was checked. Most samples were analysed in duplicate, using the average value from the three measurements to ensure high precision. In the present study, the REE analyses have a reproducibility of better than $5 \%$ (1 s.d.). The averages of the analyses are tabulated along with their analytical uncertainties (table 3 ). The whole rock REE data are from Balakrishnan and Rajamani (1987) and Mohanta (1998). The sample locations of the

Table 2. Major element abundances in titanites from Kolar and Ramagiri granitoid rocks of Dharwar craton, southern India.

\begin{tabular}{|c|c|c|c|c|c|c|}
\hline Oxide (\%) & L-1 & L-3 & $\mathrm{K}-4$ & $\mathrm{~K}-5$ & $\mathrm{R}-4$ & $\mathrm{R}-5$ \\
\hline $\mathrm{SiO}_{2}$ & 30.0933 & 28.4311 & 30.1468 & 30.0933 & 29.6056 & 29.3810 \\
\hline $\mathrm{TiO}_{2}$ & 35.4854 & 34.7048 & 34.6247 & 35.5071 & 35.2268 & 35.6055 \\
\hline $\mathrm{Al}_{2} \mathrm{O}_{3}$ & 1.3887 & 1.0505 & 1.4341 & 1.2055 & 1.3226 & 1.5833 \\
\hline $\mathrm{FeO}$ & 1.5811 & 1.0999 & 1.9207 & 1.3251 & 1.2582 & 1.4511 \\
\hline $\mathrm{MnO}$ & 0.1846 & 0.1538 & 0.1420 & 0.1511 & 0.1420 & 0.0813 \\
\hline $\mathrm{MgO}$ & 0.0000 & 0.0348 & 0.0365 & 0.0033 & 0.0000 & 0.0033 \\
\hline $\mathrm{CaO}$ & 29.2092 & 27.1132 & 27.8394 & 28.7349 & 29.6056 & 29.3810 \\
\hline $\mathrm{Na}_{2} \mathrm{O}$ & 0.0404 & 0.0714 & 0.0822 & 0.0270 & 0.0876 & 0.0971 \\
\hline $\mathrm{K}_{2} \mathrm{O}$ & 0.0217 & 0.0145 & 0.0434 & 0.0133 & 0.0000 & 0.0410 \\
\hline $\mathrm{Cr}_{2} \mathrm{O}_{3}$ & 0.0000 & 0.0000 & 0.0000 & 0.0000 & 0.0146 & 0.0000 \\
\hline Total REE* & 1.1973 & 1.3545 & 1.3243 & 1.5443 & 0.7710 & 0.5896 \\
\hline Total & 99.2017 & 94.0285 & 97.5941 & 98.6049 & 98.0340 & 98.2142 \\
\hline
\end{tabular}

$* \mathrm{RE}_{2} \mathrm{O}_{3}$ (including La) calculated from REE data generated using ICP-AES.

Table 3. Trace element abundances (in $\mu \mathrm{g} / \mathrm{g}$ ) in titanites from Kolar and Ramagiri granitoid rocks of Dharwar craton, southern India. The analytical uncertainty is $\sim 5 \%$.

\begin{tabular}{|c|c|c|c|c|c|c|c|c|c|c|c|}
\hline \multirow[b]{2}{*}{ Sample } & \multicolumn{7}{|c|}{ Kolar } & \multicolumn{4}{|c|}{ Ramagiri } \\
\hline & L-1 & $\mathrm{K}-1$ & $\mathrm{~K}-2$ & $\mathrm{~K}-4$ & L-3 & $\mathrm{K}-3$ & $\mathrm{~K}-5$ & $\mathrm{R}-1$ & $\mathrm{R}-3$ & $\mathrm{R}-4$ & $\mathrm{R}-5$ \\
\hline $\mathrm{Ce}$ & 3699 & 4373 & 4926 & 4728 & 4814 & 4452 & 3959 & 6463 & 3193 & 2422 & 1780 \\
\hline $\mathrm{Nd}$ & 3061 & 4107 & 3304 & 3177 & 3194 & 3806 & 4055 & 3376 & 2578 & 2093 & 1423 \\
\hline $\mathrm{Sm}$ & 774 & 1495 & 628 & 709 & 711 & 915 & 1160 & 603 & 745 & 471 & 383 \\
\hline $\mathrm{Eu}$ & 140 & 271 & 178 & 106 & 108 & 160 & 206 & 109 & 102 & 103 & 114 \\
\hline $\mathrm{Gd}$ & 726 & 1036 & 559 & 589 & 627 & 688 & 971 & 489 & 700 & 456 & 425 \\
\hline Dy & 483 & 642 & 357 & 435 & 446 & 439 & 752 & 334 & 616 & 280 & 255 \\
\hline Er & 287 & 286 & 170 & 221 & 252 & 214 & 333 & 155 & 295 & 144 & 126 \\
\hline $\mathrm{Yb}$ & 268 & 246 & 150 & 214 & 251 & 201 & 306 & 119 & 264 & 129 & 106 \\
\hline Total REE & 10278 & 13586 & 12668 & 11356 & 11616 & 11884 & 13261 & 13756 & 9375 & 6619 & 5062 \\
\hline $\mathrm{Ba}$ & - & 1764 & 123 & 55.2 & - & 280 & 88.4 & 56.5 & 100 & 53.8 & - \\
\hline Th & - & 436 & 447 & 457 & - & 470 & 3148 & 198 & 529 & 131 & - \\
\hline $\mathrm{U}$ & - & 343 & 406 & 792 & - & 288 & 413 & 97 & 336 & 168 & - \\
\hline $\mathrm{Nb}$ & - & 1781 & 2136 & 1273 & - & 1709 & 1771 & 1347 & 1070 & 635 & - \\
\hline $\mathrm{Ta}$ & - & 248 & 213 & 55.5 & - & 167 & 279 & 40.9 & 16.8 & 40.9 & - \\
\hline $\mathrm{Sr}$ & - & 211 & 138 & 88.1 & - & 100 & 133 & 110 & 173 & 49.5 & - \\
\hline $\mathrm{Sc}$ & - & 17.5 & 5.8 & 10.3 & - & 9.7 & 3.6 & 9.0 & 21.7 & 8.1 & - \\
\hline $\mathrm{Y}$ & - & 2915 & 3295 & 1529 & - & 2055 & 3193 & 1612 & 2845 & 1241 & - \\
\hline $\mathrm{Zr}$ & - & 928 & 1024 & 1754 & - & 944 & 1554 & 721 & 27301 & 43352 & - \\
\hline
\end{tabular}

Note. L-1 and K-2: Dosa granodiorite, K-1: Dod quartz diorite, K-4: Patna granodirite, L-3: Satu granodiorite, K-3: Gutapalli granodiorite, K-5: Tippanapalli granodiorite, R-1: Gangam quartz monzodiorite, R-3: Gangam granodiorite, R-4: Ramagiri quartz diorite, R-5: Chenna gneiss. 
present study are exactly the same outcrops or very close to those of Balakrishnan and Rajamani (1987) and Mohanta (1998).

The trace element concentrations of $\mathrm{Nb}, \mathrm{Ta}$, $\mathrm{Y}, \mathrm{Sc}, \mathrm{Ba}$ and $\mathrm{Pb}$ on the titanite samples were analysed at the Department of Earth Sciences, Pondicherry University, Puducherry using ICPAES (Jobin Yvon - Ultima2) after calibrating the instrument with pure elemental standards as rock standards with data for the above elements were not available. The reproducibility for the trace elements was $<5 \%$ (1 s.d.).

\section{$3.2 \mathrm{Sm}-\mathrm{Nd}$ isotope analysis}

The procedure for $\mathrm{Sm}-\mathrm{Nd}$ isotope analysis of titanite and hornblende from the granodiorites of Kolar and Ramagiri included weighing 10-20 $\mathrm{mg}$ of the mineral separates into a pre-weighed Savillex ${ }^{\circledR}$ beaker and digestion with $\mathrm{HF}+\mathrm{HNO}_{3}+\mathrm{HCl}$ at $110^{\circ} \mathrm{C}$ on a hot plate. Approximately $200 \mathrm{mg}$ of -200 mesh whole rock powder was also digested in a similar way. After drying, the beaker contents were dissolved in $1 \mathrm{~N} \mathrm{HCl}$ and split into two fractions. One of them was used for the determination of the isotopic composition (IC) of Sr and Nd while the other was used for the determination of $\mathrm{Rb}, \mathrm{Sr}, \mathrm{Sm}$ and Nd concentrations by isotope dilution (ID). The IC and ID fractions were eluted with $2 \mathrm{~N} \mathrm{HCl}$ in columns filled with Bio-Rad
AG50-WX8 cation-exchange resin to remove major and trace elements. The REE as a group was collected with $6 \mathrm{~N} \mathrm{HCl}$. The eluted REE were dried and dissolved in $200 \mu \mathrm{l}$ of $0.18 \mathrm{~N} \mathrm{HCl}$, and the IC and ID REE fractions were passed through HDEHP columns for separation of $\mathrm{Nd}$ and $\mathrm{Sm}$ following procedures modified from Richard et al (1976) and Gioia and Pimentel (2000). The Sm and $\mathrm{Nd}$ isotope analyses were carried out using a thermal ionisation mass spectrometer (Triton-Thermo Finnigan) at Pondicherry University.

The ${ }^{152} \mathrm{Sm}$ and ${ }^{150} \mathrm{Nd}$ tracer solution concentrations were determined accurately by analysing them against calibrating solutions (prepared from 99.9\% pure form of Sm and Nd metals of Johnson Matthey Company provided by Prof. V Rajamani, Jawaharlal Nehru University, New Delhi) repeatedly using the TIMS. The tracer solution concentrations were rechecked against Ames high purity $\mathrm{Sm}$ and Nd metals provided by Prof. K Mezger, University of Muenster, Germany.

During the course of this study $\mathrm{Nd}$ isotope standard La Jolla (provided by Dr G Lugmair, Scripps Institution of Oceanography, USA) was run repeatedly. Instrumental mass fractionation during the determination of $\mathrm{Nd}$ isotopic compositions in standards and samples was corrected by internally normalizing the measured ratios by the ratio ${ }^{146} \mathrm{Nd} /{ }^{144} \mathrm{Nd}=0.721878$ using exponential fractionation law. The mean value obtained on

Table 4. Nd and Sm isotopic data for mineral separates and whole rock samples of Patna Granite from Kolar area and Gangam quartz monzodiorite from Ramagiri area along with Nd isotopic compositions and elemental concentrations of Sm and $N d$ determined for Rock Standards BHVO-1 and BCR-2. The recommended values (Mahoney et al 2003 and URL: http://minerals.cr.usgs.gov/geochem) are also given in the table. The errors are in the $1 \sigma$ level and the decay constant used for ${ }^{147} \mathrm{Sm}$ is $\lambda=6.54 \times 10^{-12} y^{-1}$.

\begin{tabular}{|c|c|c|c|c|c|}
\hline \multicolumn{2}{|l|}{ Sample } & $\mathrm{Sm}(\mathrm{ppm})$ & $\mathrm{Nd}(\mathrm{ppm})$ & ${ }^{143} \mathrm{Nd} /{ }^{144} \mathrm{Nd} \pm \mathrm{SE}$ & ${ }^{147} \mathrm{Sm} /{ }^{144} \mathrm{Nd}$ \\
\hline \multicolumn{6}{|c|}{ Patna granite from Kolar area (K-4) } \\
\hline \multicolumn{2}{|c|}{ Titanite } & 692 & 3418 & $0.511432 \pm 3$ & 0.1224 \\
\hline \multicolumn{2}{|c|}{ Hornblende } & 13.0 & 86.3 & $0.510891 \pm 4$ & 0.0907 \\
\hline \multicolumn{2}{|c|}{ Whole rock } & 8.5 & 49.8 & $0.510980 \pm 4$ & 0.1030 \\
\hline \multicolumn{2}{|c|}{ Whole rock* } & 6.9 & 43.6 & $0.510951 \pm 9$ & 0.0950 \\
\hline \multicolumn{6}{|c|}{ Ramagiri quartz monzodiorite from Ramagiri area (R-1) } \\
\hline \multicolumn{2}{|c|}{ Titanite } & 662 & 3863 & $0.511062 \pm 4$ & 0.1036 \\
\hline \multicolumn{2}{|c|}{ Hornblende } & 39.3 & 541 & $0.510065 \pm 4$ & 0.0439 \\
\hline \multicolumn{2}{|c|}{ Whole rock } & 17.3 & 107 & $0.510951 \pm 3$ & 0.0982 \\
\hline \multicolumn{6}{|c|}{ International rock standards } \\
\hline \multirow[t]{3}{*}{ BHVO-1 } & Recommended & $6.2 \pm 0.3$ & $25 \pm 2$ & $0.512973 \pm 6$ & \\
\hline & Analysis 1 & 6.2 & 24.9 & $0.512981 \pm 3$ & \\
\hline & Analysis 2 & 6.3 & 25.2 & $0.512958 \pm 4$ & \\
\hline \multirow[t]{4}{*}{ BCR-2 } & Recommended & $6.7 \pm 0.3$ & $28 \pm 2$ & $0.512639 \pm 6$ & \\
\hline & Analysis 1 & 6.6 & 28.8 & $0.512626 \pm 4$ & \\
\hline & Analysis 2 & 6.5 & 28.6 & $0.512628 \pm 4$ & \\
\hline & Analysis 3 & 6.5 & 28.6 & $0.512621 \pm 4$ & \\
\hline
\end{tabular}

*Krogstad et al (1995). 
30 analyses of the La Jolla standard during this study for ${ }^{143} \mathrm{Nd} /{ }^{144} \mathrm{Nd}$ is $0.511848 \pm 4$ (reference value: $0.511850 \pm 10$, Lugmair and Carlson 1978; Govindaraju 1994). Nd isotope compositions and elemental concentrations of $\mathrm{Sm}$ and $\mathrm{Nd}$ for the rock standards BHVO-1 and BCR-2 were verified periodically to assess the analytical quality (see table 4).

\section{Analytical results}

The titanite samples analysed from the Kolar and Ramagiri granitoid rocks have high abundances of REE (tables 2 and 3). Whole rock-normalized REE plots (figure 4) are useful in understanding the distribution of REE between titanite and the host rock, and allow direct comparison with mineralmelt distribution coefficients. The whole rock normalized REE values are given in table 5. In the Kolar samples, titanite is invariably enriched in the MREE relative to their host rocks, with negative $\mathrm{Eu}$ anomaly (figure 4a, b). The sample K-4 (Patna granitoid) shows lower whole rock-normalized REE values, except for $\mathrm{Ce}$, than $\mathrm{K}-1$ (quartz diorite from the Dod-Dosa gneiss). Titanite from L-1 and K-2 (Dosa granodiorites) show higher whole rocknormalized REE values than that of K-1 (Dod quartz diorite).

Titanite/whole REE rock patterns for the samples east of the Kolar schist belt (figure 4b) are similar and show an enrichment of HREE relative to the host granitoid rocks. The whole rocknormalized REE values of titanite from the eastern Kambha gneisses (L-3, K-3 and K-5) are relatively higher than that of the western granitoid rocks from Dod, Dosa and Patna plutons (L-1, K-1, K-2 and $\mathrm{K}-4$ ). Additionally, the negative Eu anomaly is more pronounced in the titanites from the eastern granitoid rocks (L-3 and K-3).

Figure 4(c) shows the whole rock-normalized REE patterns for titanite from the granitoid rocks surrounding the Ramagiri schist belt. The titanite from the western Gangam quartz monzodiorite (R-1) has an almost flat whole rock-normalized REE pattern, despite the fact that the titanite and the corresponding rock have elevated REE abundances compared to the rest of the granitoid rocks as reflected in the low titanite/whole rock REE values (tables 3 and 5). Conversely, titanite from a granodiorite that occurs along with the Gangam quartz monzodiorite (R-3) show an HREE-enriched pattern with high negative $\mathrm{Eu}$ anomaly. Quartz diorite (R-4) from the central Ramagiri complex has a pattern similar to that of the Gangam granodiorite (R-3). Titanite from the Chenna gneisses (R-5) east of the Ramagiri schist belt has higher titanite/whole rock REE values
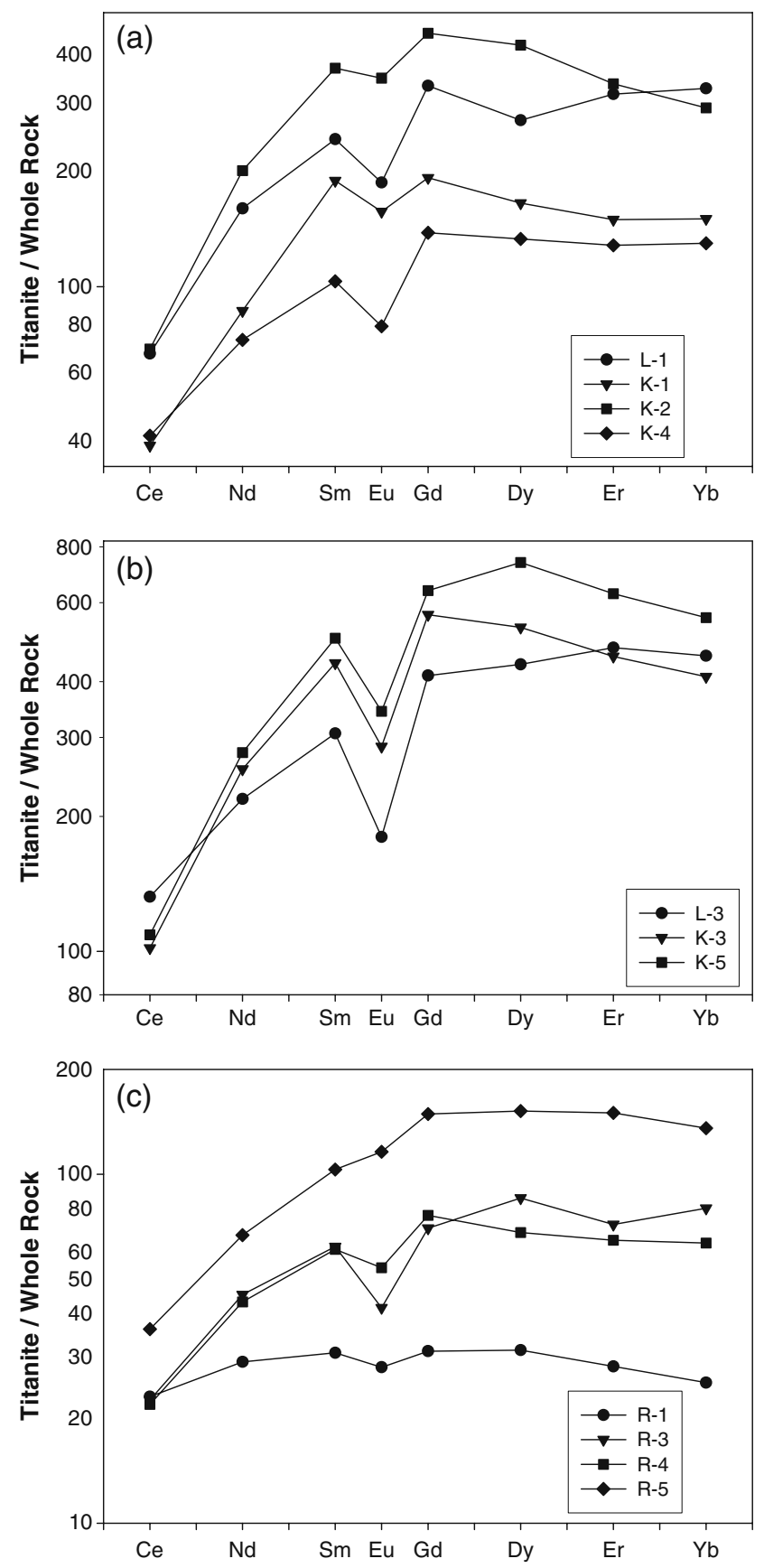

Figure 4. (a) Whole rock-normalized plot for the REE of titanites from the granitoid rocks occurring west of the Kolar schist belt. The titanite/whole rock REE values for the titanites from granodiorites are higher than those for the titanites from Patna granitoid. (b) Whole rock-normalized plot for the REE of titanites from the granitoid rocks occurring east of the Kolar schist belt. The titanites have shown lower titanite/whole rock values for the LREE relative to the HREE with well pronounced negative Eu anomaly. (c) Whole rock-normalized plots for the REE of titanites from the granitoid rocks surrounding the Ramagiri schist belt. The titanites from the quartz monzodiorite from the western Gangam complex have shown low titanite/whole rock REE values with a near flat pattern, whereas, the titanites from the granodiorite from the Gangam complex and quartz diorite from the Ramagiri complex show a LREEdepleted, HREE-enriched titanite/whole rock REE pattern with negative Eu anomaly. The Chenna gneisses show high titanite/whole rock REE values with little or no Eu anomaly. 
Table 5. Whole rock-normalized REE data of titanite from Kolar and Ramagiri granitoid rocks of Dharwar craton, southern India.

\begin{tabular}{lrrrrrrrrrrr}
\hline & \multicolumn{1}{c}{ L-1 } & \multicolumn{1}{c}{ K-1 } & \multicolumn{1}{c}{ K-2 } & \multicolumn{1}{c}{ K-4 } & L-3 & K-3 & K-5 & R-1 & R-3 & R-4 & R-5 \\
\hline Ce & 67.08 & 38.74 & 68.97 & 41.13 & 132.25 & 101.63 & 108.78 & 23.04 & 22.57 & 21.90 & 35.98 \\
Nd & 159.52 & 86.59 & 199.71 & 72.82 & 218.79 & 254.95 & 277.75 & 28.98 & 45.22 & 43.09 & 66.98 \\
Sm & 241.13 & 188.31 & 368.39 & 103.32 & 306.60 & 440.03 & 500.02 & 30.78 & 62.07 & 60.96 & 103.21 \\
Eu & 186.17 & 156.45 & 346.95 & 79.00 & 180.02 & 286.40 & 343.21 & 27.98 & 41.48 & 53.94 & 116.07 \\
Gd & 331.51 & 191.44 & 453.61 & 137.90 & 412.66 & 563.89 & 638.51 & 31.13 & 70.04 & 76.23 & 148.95 \\
Dy & 269.85 & 164.65 & 422.63 & 132.89 & 436.85 & 528.43 & 737.73 & 31.34 & 85.53 & 68.09 & 151.89 \\
Er & 315.47 & 149.11 & 335.77 & 127.94 & 476.14 & 455.15 & 628.54 & 28.14 & 71.84 & 64.72 & 150.06 \\
Yb & 326.34 & 149.95 & 290.62 & 129.53 & 456.57 & 410.19 & 555.76 & 25.29 & 79.91 & 63.55 & 135.69 \\
\hline
\end{tabular}
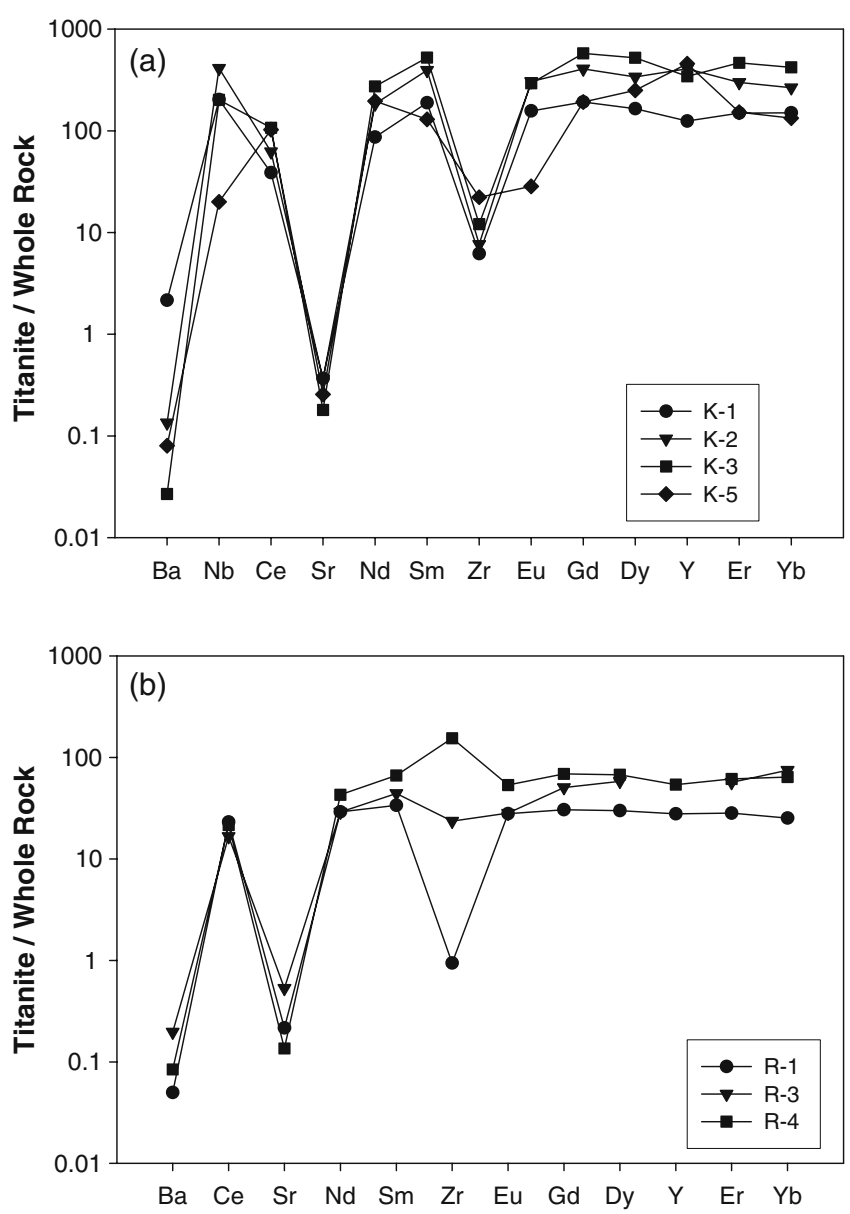

Figure 5. The abundances of trace elements in titanite mineral separates from the granitoid rocks surrounding the Kolar and Ramagiri schist belts normalized to their respective whole rocks. (a) Kolar granitoid rocks: The titanites have higher whole rock-normalized values for high field strength elements (HFSE) such as Nb, Y, Zr and REE while the whole rock-normalized values for $\mathrm{Ba}$ and $\mathrm{Sr}$ are low. The whole rock-normalized value for $\mathrm{Zr}$ is less than that for the REE but greater than one. (b) Ramagiri granitoid rocks: The titanites have higher whole rock-normalized values for High Field Strength Elements (HFSE) such as $\mathrm{Y}$ and REE while the whole rock-normalized values for $\mathrm{Ba}$ and $\mathrm{Sr}$ are low. Except the quartz monzodiorite, R1 , the samples have higher whole rock-normalized value for $\mathrm{Zr}$.
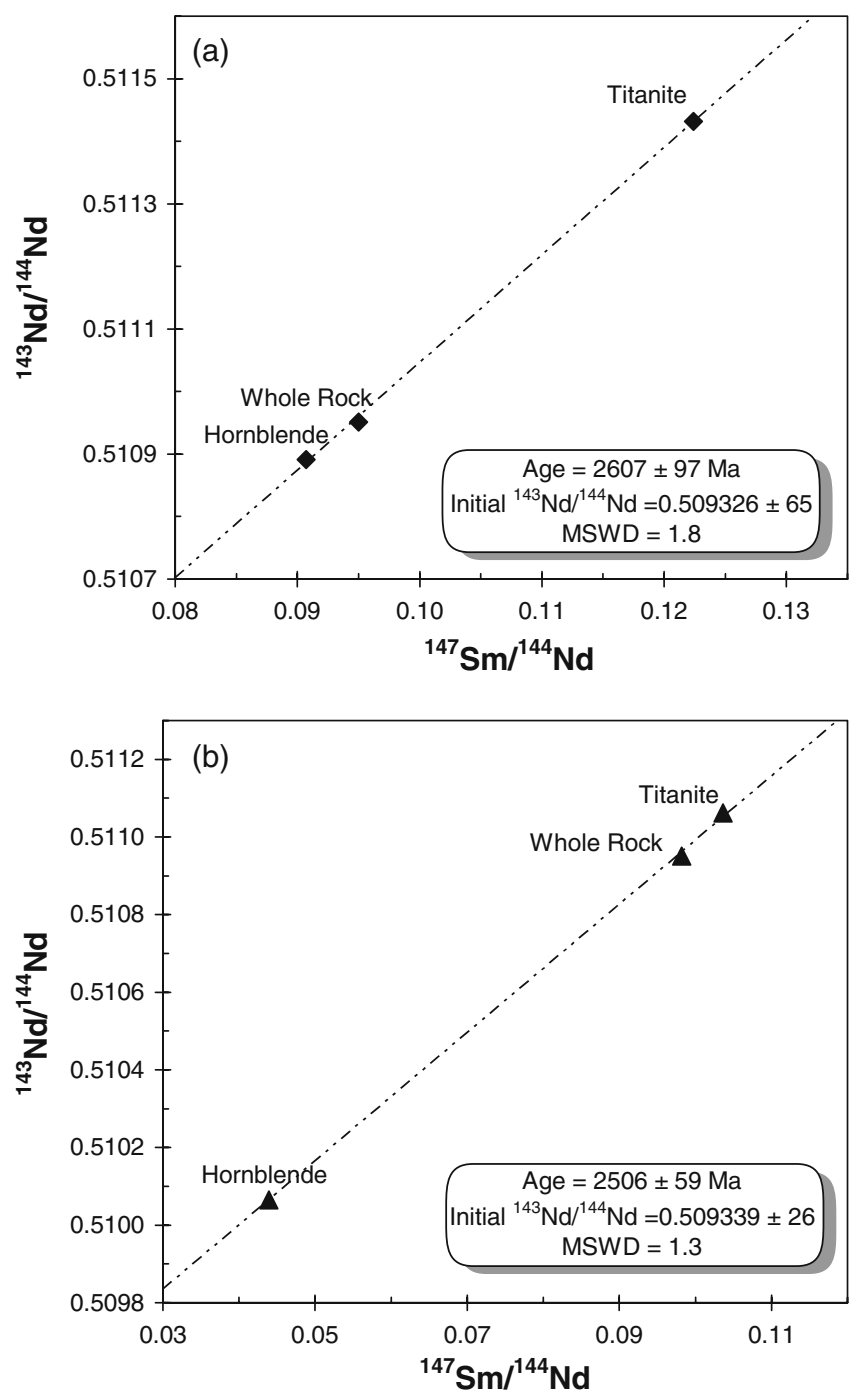

Figure 6. (a) Sm-Nd mineral isochron diagram for titanite and hornblende mineral separates along with the whole rock (Krogstad et al 1991) from Patna granite occurring to the west of the Kolar schist belt. The $2607 \pm 97 \mathrm{Ma}$ age obtained is indistinguishable from the more precise $\mathrm{U}-\mathrm{Pb}$ zircon and titanite ages of $2551 \pm 2.5 \mathrm{Ma}$ and $2552 \pm 1 \mathrm{Ma}$, respectively (Krogstad et al 1991). (b) Sm-Nd mineral isochron diagram for titanite and hornblende mineral separates and whole rock from Gangam quartz monzodiorite occurring to the west of the Ramagiri schist belt. The $2506 \pm 59 \mathrm{Ma}$ age obtained is indistinguishable from the more precise $\mathrm{U}-\mathrm{Pb}$ titanite age of $2510 \pm 2 \mathrm{Ma}$ (Balakrishnan et al 1999). 
relative to titanite from the rest of the granitoid samples, showing a progressive increase in the HREE content.

Trace element abundances of $\mathrm{Ba}, \mathrm{Nb}, \mathrm{Sr}, \mathrm{Zr}$, $\mathrm{Y}$ and REE in titanite (table 3) normalized to their respective whole rocks (table 5) are plotted in figure $5(\mathrm{a}$ and $\mathrm{b})$. Niobium is not shown in figure 5(b) because $\mathrm{Nb}$ data for whole rocks from Ramagiri are not available. All titanite samples are enriched in $\mathrm{Nb}, \mathrm{Y}$ and $\mathrm{Zr}$, and have lower abundances of $\mathrm{Ba}$ and $\mathrm{Sr}$ relative to the whole rock. Two of the titanites (from R-3 and R-4) from the Ramagiri area have much higher abundances of $\mathrm{Zr}$ compared to other samples.

$\mathrm{Sm}-\mathrm{Nd}$ isotopic data obtained on titanite and hornblende mineral fractions, and whole rock for the two samples of Patna granitoid (K-4) and Gangam quartz monzodiorite (R-1) are given in table 4 . The calculated $\mathrm{Sm}-\mathrm{Nd}$ isochron age (figure $6 \mathrm{a}$, the whole rock data from Krogstad et al (1995) was used for this calculation as it gave better spread) obtained for the Patna granitoid (K-4) is $2607 \pm 97 \mathrm{Ma}(\mathrm{MSWD}=1.8)$, which agrees with analytical uncertainties with the reported $\mathrm{U}-\mathrm{Pb}$ zircon and titanite ages of $2551 \pm 2.5 \mathrm{Ma}$ and $2552 \pm 1$ ma, respectively (Krogstad et al 1991) for this rock. The whole rock-mineral isochron age (figure 6b) for the Gangam quartz monzodiorite $(\mathrm{R}-1)$ is $2506 \pm 59 \mathrm{Ma}(\mathrm{MSWD}=1.3)$, which also agrees with the $\mathrm{U}-\mathrm{Pb}$ titanite age of $2510 \pm 2 \mathrm{Ma}$ reported by Balakrishnan et al (1999). The reported $\mathrm{U}-\mathrm{Pb}$ titanite and zircon ages for the associated Gangam granodiorite are $2516 \pm 3$ Ma and $2528 \pm 1 \mathrm{Ma}$, respectively (Balakrishnan et al 1999).

\section{Discussion}

\subsection{Distribution of REE between titanite and whole rock}

The REEs in titanite are accommodated in the seven-fold co-ordinated $\mathrm{Ca}^{2+}$ site (Huges et al 1997; Frost et al 2000). Charge balance is maintained by coupled substitutions, with $\mathrm{Al}^{3+}$ and $\mathrm{Fe}^{3+}$ as potential substitutions in the $\mathrm{Ti}^{4+}$ (Franz and Spear 1985; Pan et al 1993; Frost et al 2000). Therefore, the possible substitution mechanisms as suggested by Green and Pearson (1986) are:

$$
\begin{gathered}
\mathrm{Ca}^{2+}+\mathrm{Ti}^{4+} \leftrightarrow \mathrm{REE}^{3+}+\mathrm{Al}^{3+}, \\
\mathrm{Ca}^{2+}+\mathrm{Si}^{4+} \leftrightarrow \mathrm{REE}^{3+}+\mathrm{Al}^{3+}
\end{gathered}
$$

or

$$
\mathrm{Ca}^{2+}+\mathrm{Ti}^{4+} \leftrightarrow \mathrm{REE}^{3+}+\mathrm{Fe}^{3+} .
$$

The distribution of trace elements between a mineral and magma is denoted by the partition coefficient $K_{d}$ (Hanson 1978). The partition coefficient is dependent on several factors such as temperature, composition, oxygen fugacity and to a lesser extent on pressure (Watson 1976; Rollinson 1993; Adam and Green 1994; Prowatke and Klemme 2005). Temperature is the major factor controlling the partition coefficient $\left(K_{d}\right)$, in most mineral-melt systems with which it has an inverse relationship (Rollinson 1993; Tiepolo et al 2002). Compositional effect on the partition coefficient of REE is also important (Watson 1976; Hanson 1978; Ryerson and Hess 1978; Green and Pearson 1986, 1987; Rollinson 1993; Tiepolo et al 2002; Prowatke and Klemme 2005).

The rocks from Kolar and Ramagiri considered here are assumed to be representative of the melts from which they were derived. Also, it is assumed that the post-crystallization alteration events have not changed the bulk composition of the rocks. Based on these assumptions the mineral-whole rock $K_{d}$ values are considered further as approximations of mineral-melt $K_{d}$ values. Igneous titanites from the Patna granitoid (K-4) occurring to the west of the Kolar schist belt show low $K_{d}$ values for the REE. The REE pattern is MREE-enriched with a small negative $\mathrm{Eu}$ anomaly (figure 4a). Titanite from the granodiorite gneisses Dod and Dosa (L-1, K-1 and K-2), occurring to the west of the Kolar schist belt that were affected by metamorphism show similar REE patterns, but with higher $K_{d}$ values for the REE than the Patna granitoid (K-4).

The Kambha gneisses show structures and textures indicative of migmatization and partial anatexis that took place soon after emplacement of their precursors (Balakrishnan and Rajamani 1987). They are younger than the western Dod and Dosa gneisses and the titanites show higher whole rock normalized values than the western granitoid rocks (figure $4 \mathrm{~b}$ ).

Low temperature crystallization of megacrystic titanites of Kambha gneisses during migmatization may have caused the enrichment of all REEs except $\mathrm{Eu}$ in them relative to the host rock (L-3, K-3 and K-5). Experimental studies by Green and Pearson (1986) have shown that at low temperatures of crystallization titanite shows higher enrichment of REE relative to those crystallized at high temperatures. They have also described the discrimination against Eu in the titanite structure. The resulting high negative $\mathrm{Eu}$ anomaly in these titanites can be attributed to partitioning of Eu into the feldspars, which are the major mineral phase, under low $f_{\mathrm{O}_{2}}$ conditions. This must have resulted in considerable enrichment of REE (except $\mathrm{Eu}$ ) and $\mathrm{U}$ in these titanites.

In the Ramagiri area, titanite from quartz diorite of the Ramagiri complex (R-4) and from granodiorite of the Gangam complex (R-3), have 
identical whole rock normalized REE patterns (figure 4c). The quartz monzodiorite from the Gangam complex (R-1) displays an approximately flat titanite/ whole rock pattern, with very little variations in the REE (figure 4c). But it can be noted from tables 3 and 5 that the REE abundances in the titanite and the corresponding rock are high particularly for the LREE. A higher temperature of crystallization could explain the high REE contents in the quartz monzodiorite, relative to the coexisting and coeval granodiorite. The compositional dependence of REE partitioning between titanite and melt has been studied earlier based on experimental compositions for melt (Tiepolo et al 2002; Prowatke and Klemme 2005, 2006). It has been argued that the activity of aluminium in the melt system controls the incorporation of REE in minerals (Prowatke and Klemme 2005). This phenomenon can explain the relatively low REE enrichment in titanite from quartz monzodiorite as compared to the coexisting granodiorite, albeit the former rock and its titanite have higher REE abundances. In the case of Chenna gneisses (R-5), titanite which yielded $\mathrm{U}-\mathrm{Pb}$ ages about $100 \mathrm{Ma}$ younger than the zircons have higher whole rocknormalized REE values (figure 4c). One possible explanation for the difference is that the metamorphic/migmatitic event brought about an enrichment of the REE in the titanite relative to their respective whole rocks. Therefore, it is suggested that the REE, $\mathrm{U}$ and $\mathrm{Pb}$ in the titanite were reequilibrated during migmatization of both Kambha and Chenna gneisses from Kolar and Ramagiri areas, respectively.

\subsection{Titanite-melt equilibria}

Titanites have a high density $\left(3.48-3.60 \mathrm{gm} / \mathrm{cm}^{3}\right)$ (Deer et al 1992) and a wedge-shaped habit which together might facilitate their gravity settling in magmas. Titanite crystals could therefore be effectively removed from granodioritic magma by fractional crystallization (Basir and Balakrishnan 1999). Since the $K_{d}$ values for REE in titanite vary due to differences in the conditions of their formation, fractional crystallization of titanite can give rise to residual magmas with different REE patterns (Stern and Hanson 1991; Basir and Balakrishnan 1999). To illustrate this principle, a granodioritic (approximately) composition was considered for modelling of REE and Nb abundances in a granodioritic magma fractionating titanite. We assume that the titanite crystals were effectively removed from the melt at the instant they were formed. Thus we employ Rayleigh's fractionation equation

$$
\frac{C_{\mathrm{L}}}{C_{0}}=F^{(D-1)}
$$

where $C_{\mathrm{L}}$ is the concentration of the trace element in the residual liquid, $C_{0}$ is the initial concentration of the trace element in the primary magma, $F$ is the fraction of melt remaining, and $D\left(=K_{d}\right.$ in this case) is the partition coefficient of the fractionating mineral phase. Results from the modelling suggest that as low as $2 \%$ fractional crystallization of the titanites is sufficient to deplete the REE and $\mathrm{Nb}$, and introduce significant positive $\mathrm{Eu}$ anomaly in the residual granodioritic magmas (figure 7a).

Based on phase equilibria, trace element and isotope studies, it has been shown that granitic and granodioritic magmas could be derived by partial melting of pre-existed granitoid rocks (Balakrishnan and Rajamani 1987; Jayananda et al 1992; Krogstad et al 1995; Basir and Balakrishnan 1999). Partial melting of granodiorite leaving a residue consisting of $63-58 \%$ plagioclase, $12 \%$ clinopyroxene, $5 \%$ orthopyroxene, $15 \%$ quartz and $5 \%$ amphibole, with or without titanite $(0-5 \%)$, was modeled for different degrees of partial melting. It was observed that the REE concentration depends chiefly in the presence of titanite in the residual mineralogy, and to a lesser extent on different extents of partial melting.

The equation for batch melting, also known as equilibrium partial melting was also applied.

$$
\frac{C_{\mathrm{L}}}{C_{0}}=\frac{1}{D_{\mathrm{RS}}+F\left(1-D_{\mathrm{RS}}\right)},
$$

where $C_{\mathrm{L}}$ is the concentration of trace element in the melt, $C_{0}$ is the concentration in the unmelted source, $D_{\mathrm{RS}}$ is the bulk partition coefficient of the residual solid and $F$ is the weight fraction of melt produced. The REE and $\mathrm{Nb}$ abundances in the melt formed by $10 \%$ partial melting of granodiorites are displayed in figure $7(\mathrm{~b})$. From these plots we can infer that the melt formed with a titanite absent residue has higher REE and $\mathrm{Nb}$ abundances (figure $7 \mathrm{~b}$ ). The presence of even $1 \%$ titanite in the residue significantly lowers the abundances of REE and $\mathrm{Nb}$ in the parent melt (figure $7 \mathrm{~b}$ ).

Trace element analysis on titanite from Kolar and Ramagiri granitoid rocks displays high whole rock-normalized values for $\mathrm{Nb}, \mathrm{Y}$ and $\mathrm{Zr}$ (figure 5). The $\mathrm{Nb}$ enrichment in titanite is expected, given its substitution for Ti. The behaviour of $\mathrm{Nb}$ present in titanite during fractional crystallization of titanite and partial melting of intermediate rocks, is similar to that of the REE (figure $7 \mathrm{a}$ and $\mathrm{b}$ ). Thus the presence of titanite as a residual phase needs to be considered when modelling petrogenesis of granitoid rocks.

Two samples, R-3 and R-4, have elevated Zr concentrations relative to the whole rock (figure $5 \mathrm{~b}$ ) which can be attributed to either the presence of zircon inclusions in titanite, or possible impure mineral separation, or Zr incorporated in 

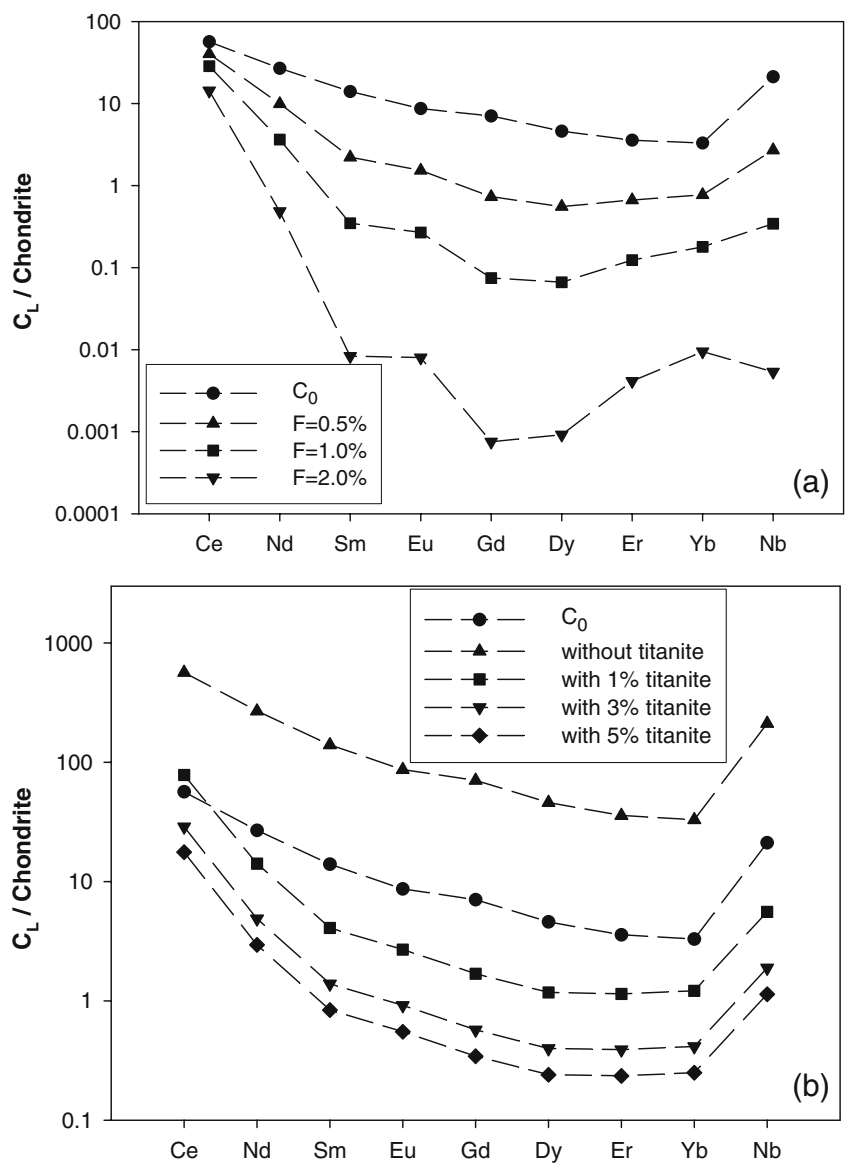

Figure 7. (a) Fractional crystallization modelling involving removal of $0.5 \%, 1 \%$ and $2 \%$ titanites from the granodioritic magma. As low as $2 \%$ fractional crystallization of the titanites is sufficient to deplete the REE and $\mathrm{Nb}$ and introduce significant positive $\mathrm{Eu}$ anomaly in the residual granodioritic magmas. (b) Partial melting modelling of granodiorites formed by $10 \%$ partial melting leaving a residue consisting of $63-58 \%$ plagioclase, $12 \%$ clinopyroxene, $5 \%$ orthopyroxene, $15 \%$ quartz and $5 \%$ amphibole with or without titanite $(0-5 \%)$. Partial melting of granodiorites leaving even very low model abundances of titanite in the resultant residue significantly depletes the REE and $\mathrm{Nb}$ when compared to partial melting without leaving titanite in the residue. Similarly, U, Th and Y will be depleted in magmas that have equilibrated with titanite.

titanite structure. The grains were handpicked under the microscope before digestion and therefore the question of impure mineral separation is ruled out. $\mathrm{Zr}$ accommodation in chiefly silica undersaturated alkaline rocks and silica-saturated rocks rich in alkalis such as lamprophyres which were reported by Seifert and Kramer (2003) and Seifert (2005). These authors argue that in the absence of zircon, $\mathrm{Zr}$ susbstitutes $\mathrm{Ti}$ in titanite in lamprophyres by coupled substitution with $\mathrm{Fe}^{3+}$ replacing $\mathrm{Al}^{3+}$. Also $\mathrm{Zr}$ substitutes Th-rich ferroan titanite in silica-saturated rocks. As in the present case the samples do not show high Fe content (table 2) and as zircon is a common accessory mineral it cannot be argued in favour of Zr substitution. Therefore, higher $\mathrm{Zr}$ content in the above two samples can be attributed to the presence of sub-microscopic zircon inclusions in titanite.

\section{$5.3 \mathrm{Sm}-\mathrm{Nd}$ mineral isochron study}

The Sm-Nd mineral isochron study on titanite, hornblende and whole rock samples from Patna granitoid (K-4) occurring north of the Kolar schist belt has given an age of $2607 \pm 97 \mathrm{Ma}$. This age is indistinguishable from the much more precise $\mathrm{U}-\mathrm{Pb}$ age of $2552 \pm 1 \mathrm{Ma}$ for titanites and $2551 \pm$ 2.5 Ma for zircons (Krogstad et al 1991). The titanite, hornblende and whole rock age for the Gangam quartz monzodiorite (R-1) occurring west of the Ramagiri schist belt have given an isochron age of $2506 \pm 59 \mathrm{Ma}$. This age is indistinguishable from the precise $\mathrm{U}-\mathrm{Pb}$ titanite age of $2510 \pm 2 \mathrm{Ma}$ (Balakrishnan et al 1999). Thus, the Sm-Nd system in minerals and whole rock is robust to give reliable age information in the absence of $\mathrm{U}-\mathrm{Pb}$ isotope dating techniques. However, the uncertainty on mineral isochron ages is high, which can be reduced by including more minerals that have a range of $\mathrm{Sm} / \mathrm{Nd}$ ratios and were closed to $\mathrm{Sm}$ and $\mathrm{Nd}$ diffusion at temperatures similar to the closure temperature of titanites.

\section{Conclusions}

Titanite crystallized at lower temperature during migmatization have higher REE and HFSE abundances than those formed at higher temperatures such as during igneous crystallization of quartz diorites or granodiorites. The titanite REE abundances and their distribution in the host rocks are influenced by differences in the original composition of granitoid magmas. It is shown that the presence of as little as $1 \%$ of titanite in residual phases during partial melting or in residual melts during fractional crystallization can significantly lower the abundances of trace elements, such as $\mathrm{Nb}$, $\mathrm{Y}, \mathrm{Zr}$ and REE. Therefore, titanite plays a major role in controlling the trace element distribution in host granitoid rocks.

$\mathrm{Sm}-\mathrm{Nd}$ mineral isochron study on titanite and hornblende from two granitoid rocks from Kolar and Ramagiri areas have given ages that are in good agreement with the more precise $\mathrm{U}-\mathrm{Pb}$ dates for these samples. Therefore, in the absence of $\mathrm{U}-\mathrm{Pb}$ ages, $\mathrm{Sm}-\mathrm{Nd}$ mineral isochrons can be used to obtain reliable age information.

\section{Acknowledgements}

We thank Prof. V Rajamani (Jawaharlal Nehru University, New Delhi) for extending ICP-AES facilities during the analysis of the REEs. We also 
thank Prof. B Basavalingu (Mysore University) for extending EPMA facilities for the major element analysis. RA was supported by the research fellowship of CSIR. The Central Instrumentation Facility of Pondicherry University was utilized for the SEM study on the titanite samples.

\section{References}

Adam J and Green T H 1994 The effect of pressure and temperature on the partitioning of $\mathrm{Ti}$, Sr, and REE between amphibole, clinopyroxene and basanitic melts; Chem. Geol. 117 219-233.

Balakrishnan S and Rajamani V 1987 Geochemistry and petrogenesis of granitoids around Kolar schist belt, south India: Constraints for the evolution of the crust in the Kolar area; J. Geol. 95 219-240.

Balakrishnan S, Rajamani V and Hanson G N 1999 U-Pb ages for zircon and titanite from the Ramagiri area, southern India: Evidence for accretionary origin of the eastern Dharwar craton during the late Archean; J. Geol. 107 69-86.

Basir S R and Balakrishnan S 1999 Geochemistry of sphene from granitoids surrounding the Hutti-Maski Schist Belt: Significance to rare earth element (REE) modelling; J. Geol. Soc. India 54 107-119.

Bea F 1996 Residence of REE, Y, Th and U in granites and crustal protoliths; implications for the chemistry of crustal melts; J. Petrol. 37 521-552.

Chadwick B, Ramakrishnan M and Viswanatha M N 1981a The stratigraphy and structure of the Chitradurga region: An illustration of cover-basement interaction in Late Archean evolution of the Karnataka craton, Southern India; Precamb. Res. 16 31-54.

Chadwick B, Ramakrishnan M and Viswanatha M N 1981b Structural and metamorphic relations between Sargur and Dharwar supracrustal rocks and Peninsular Gneiss in central Karnataka; J. Geol. Soc. India 22 557-569.

Chadwick B, Ramakrishnan M and Viswanatha M N 1985a Bababudan - A Late Archean intracratonic volcanosedimentary basin, Karnataka, Southern India. Part I: Stratigraphy and Basin Development; J. Geol. Soc. India 26 769-801.

Chadwick B, Ramakrishnan M and Viswanatha M N 1985b Bababudan - A Late Archean intracratonic volcanosedimentary basin, Karnataka, Southern India. Part II: Structure; J. Geol. Soc. India 26 802-821.

Chadwick B, Vasudev V N, Krishna Rao B and Hegde G V 1992 The Dharwar supergroup: Basin development and implications for Late Archean tectonic setting in western India, southern India; In: The Archean: Terrains, Processes and Metallogeny (eds) Glover J E and Ho S (University of Western Australia Publ.) vol. 22, pp. 3-15.

Chadwick B, Vasudev V N and Ahmed N 1996 The Sandur Schist belt and its adjacent plutonic rocks: Implications for Late Archean crustal evolution in Karnataka; J. Geol. Soc. India 47 37-57.

Chadwick B, Vasudev V N and Hegde G V 2000 The Dharwar craton, southern India, interpreted as the result of Late Archean oblique convergence; Precamb. Res. 99 91-111.

Corfu F and Stone D 1998 The significance of titanite and apatite $\mathrm{U}-\mathrm{Pb}$ ages: Constraints for the post-magmatic thermal-hydrothermal evolution of a batholithic complex, Berens river area, northwestern Superior Province, Canada; Geochim. Cosmochim. Acta 62 2979-2995.
Deer W A, Howie R A and Zussman J 1992 An introduction to the rock-forming minerals (Harlow, Essex: Longman) $696 \mathrm{pp}$.

DePaolo D J and Wasserburg G J 1979 Sm-Nd age for the Stillwater complex and the mantle evolution curve for neodymium; Geochim. Cosmochim. Acta 43999 1008.

Fleischer M and Altschuler Z S 1969 The relationship of the rare-earth composition of the minerals to geological environment; Geochim. Cosmochim. Acta 33 725-732.

Franz G and Spear F S 1985 Aluminous titanite (sphene) from the eclogite zone, South Central Tauern Window, Austria; Chem. Geol. 50 33-46.

Frost B R, Chamberlain K R and Schumacher J C 2000 Sphene (titanite): Phase relations and role as a geochronometer; Chem. Geol. 172 131-145.

Futa K 1981 Sm-Nd systematics of a tonalitic augen gneiss and its constituent minerals from northern Michigan; Geochim. Cosmochim. Acta 45 1245-1249.

Ghosh D B, Sastry B B K, Rao A J and Rahim A A 1970 Ore environment and ore genesis in Ramagiri gold field, Andhra Pradesh, India; Econ. Geol. 65 801-814.

Gieré R 1992 Compositional variation of metasomatic titanite from Adamello, Italy; Swiss Bull. Mineral. Petrol. 72 167-177.

Gioia S M C L and Pimentel M M 2000 The Sm-Nd isotopic method in the geochronology laboratory of the University of Brasília; An. Acad. Bras. Ci. 72 219-245.

Govindaraju K 1994 Compilation of working values and sample description for 383 geostandards; Geostandards Newslett. 18 1-158.

Green T H and Pearson N J 1986 Rare-earth element partitioning between sphene and coexisting silicate liquid at high pressure and temperature; Chem. Geol. $\mathbf{5 5}$ 105-119.

Green T H and Pearson N J 1987 An experimental study of $\mathrm{Nb}$ and Ta partitioning between Ti-rich minerals and silicate liquids at high pressure and temperature; Geochim. Cosmochim. Acta 51 55-62.

Gromet L P and Silver L T 1983 REE distributions among minerals in a granodiorite and their petrogenetic implications; Geochim. Cosmochim. Acta 47 925-939.

Hanson G N 1978 The application of trace elements to the petrogenesis of igneous rocks of granitic composition; Earth Planet. Sci. Lett. 38 26-43.

Huges J M, Bloodaxe E S, Hanchar J M and Foord E E 1997 Incorporation of rare earth elements in titanite: Stabilization of the A2/a dimorph by creation of antiphase boundaries; Am. Mineral. 82 512-516.

Jayananda M, Martin H and Mahabaleshwar B 1992 The mechanisms of recycling of Archean continental crust: Example of the Closepet granite, Southern India; Proc. 3rd Int. Archean Symp. Perth, pp. 213-222.

Jayananda M, Moyen J-F, Martin H, Peucat J-J, Auvray B and Mahabalesawar B 2000 Late Archaean (2550-2520 Ma) juvenile magmatism in the Eastern Dharwar craton, southern India: Constraints from geochronology, Nd-Sr isotopes and whole rock geochemistry; Precamb. Res. 99 225-254.

Krogstad E J, Balakrishnan S, Mukhopadhyay D K, Rajamani V and Hanson G N 1989 Plate tectonics 2.5 billion years ago: Evidence at Kolar, South India; Science 243 1337-1340.

Krogstad E J, Hanson G N and Rajamani V 1991 U-Pb ages of zircon and sphene for two gneiss terrains adjacent to the Kolar Schist Belt, south India: Evidence for separate crustal evolution histories; J. Geol. 99 801-816.

Krogstad E J, Hanson G N and Rajamani V 1995 Sources of continental magmatism adjacent to the Late Archean 
Kolar Suture Zone, south India: Distinct isotopic and elemental signatures of two Late Archean magmatic series; Contrib. Mineral. Petrol. 122 159-173.

Li X 1994 A comprehensive U-Pb, Sm-Nd, Rb-Sr and ${ }^{40} \mathrm{Ar}-$ ${ }^{39} \mathrm{Ar}$ geochronological study of Guidong Granodiorite, southeast China: Records of multi-tectonothermal events in a single pluton; Chem. Geol. 115 283-295.

Lugmair G W and Carlson R W 1978 The Sm-Nd history of KREEP; Proc. 9th Lunar Planet. Sci. Conf., pp. $689-704$.

Mahoney J B, Weis D, Kieffer B, Friedman R, Pretorius W, Scoates J, Goolaerts A and Maerschalk C 2003 Ongoing Isotopic Characterization of USGS Standards: MC-ICPMS and TIMS data from The Pacific Centre for Isotopic and Geochemical Research, University of British Columbia (Abst.) Abstracts with Programs, Annual Meeting; Geol. Soc. Amer. 35243.

Mezger K 1990 Geochronology in granulites; In: Granulites and Crustal Evolution (eds) Vielzeuf D and Vidal $\mathrm{Ph}$ (Dordrecht, The Netherlands: Kluwer Academic Publishers) pp. 451-470.

Mohanta M K 1998 Geochemistry and nuclear energy potential of the granitic gneisses around Ramagiri gold fields; unpubl. Ph.D. dissertation, Jawaharlal Nehru University, New Delhi, 319 pp.

Nutman A P, Chadwick B, Krishna Rao B and Vasudev V N 1996 SHRIMP U-Pb zircon ages of acid volcanic rocks in the Chitradurga and Sandur Groups, and granites adjacent to the Sandur schist belt, Karnataka; J. Geol. Soc. India 41 153-164.

Pan Y, Fleet M E and MacRae N D 1993 Late alteration in titanite $\left(\mathrm{CaTiSiO}_{5}\right)$ : Redistribution and remobilization of rare earth elements and implications for $\mathrm{U} / \mathrm{Pb}$ and $\mathrm{Th} / \mathrm{Pb}$ geochronology and nuclear waste disposal; Geochim. Cosmochim. Acta 57 355-367.

Pichamuthu C S 1965 Regional metamorphism and charnockitization in Mysore State, India; Indian Mineral. 6 119-126.

Pidgeon R T, Bosch D and Bruguier O 1996 Inherited zircon and titanite $\mathrm{U}-\mathrm{Pb}$ systems in an archaean syenite from southwestern Australia: Implications for $\mathrm{U}-\mathrm{Pb}$ stability of titanite; Earth Planet. Sci. Lett. 141 187-198.

Poitrasson F, Hanchar J M and Schaltegger U 2002 The current state and future of accessory mineral research; Chem. Geol. 191 3-24.

Prowatke S and Klemme S 2005 Effect of melt composition on the partitioning of trace elements between titanite and silicate melt; Geochim. Cosmochim. Acta 69 695-709.

Prowatke S and Klemme S 2006 Rare earth element partitioning between titanite and silicate melts: Henry's law revisited; Geochim. Cosmochim. Acta 70 49975012 .

Raase P, Raith M, Ackermand D and Lal R K 1986 Progressive metamorphism of mafic rocks from greenschist to granulite facies in the Dharwar craton of south India; J. Geol. 94 261-282.

Richard P, Shimizu N and Allègre C J $1976{ }^{143} \mathrm{Nd} /{ }^{146} \mathrm{Nd}$ a natural tracer: An application to oceanic Basalts; Earth Planet. Sci. Lett. 31 269-278.
Rollinson H R 1993 Using Geochemical Data: Evaluation, Presentation, Interpretation (Harlow, Essex: Longman) $352 \mathrm{pp}$.

Ryerson F J and Hess P C 1978 Implications of liquid-liquid distribution coefficients to mineral-liquid partitioning; Geochim. Cosmochim. Acta 42 921-932.

Ryerson F J and Watson E B 1987 Rutile saturation in magmas: Implications for $\mathrm{Ti}-\mathrm{Nb}-\mathrm{Ta}$ depletion in island-arc basalts; Earth Planet. Sci. Lett. 86 225-239.

Saini N K, Mukherjee P K, Rathi M S, Khanna P P and Purohit K K 1998 A new geochemical reference sample of granite (DG-H) from Dalhousie, Himachal Himalaya; J. Geol. Soc. India 52 603-606.

Sawka W N, Chappell B W and Norrish K 1984 Lightrare-earth-element zoning in sphene and allanite during granitoid fractionation; Geology 12 131-134.

Scott D J and St-Onge M R 1995 Constraints on Pb closure temperature based on rocks from the Ungava orogen, Canada: Implications for $\mathrm{U}-\mathrm{Pb}$ geochronology and P-T-t path determinations; Geology 23 1123-1126.

Seifert W 2005 REE-, Zr-, and Th-rich titanite and associated accessory minerals from a kersantite in Frankenwald, Germany; Mineral. Petrol. 84 129-146.

Seifert W and Kramer W 2003 Accessory titanite: An important carrier of zirconium in lamprophyres; Lithos $\mathbf{7 1}$ $81-98$.

Stern R A and Hanson G N 1991 Archean high Mg granodiorite: A derivative of light rare earth element enriched monzodiorite of mantle origin; J. Petrol. 32 201-238.

Stevenson R, Henry P and Gariépy C 1999 Assimilationfractional crystallization origin of Archean Sanukitoid Suites: Western Superior Province, Canada; Precamb. Res. 96 83-99.

Storey C D, Jeffries T E and Smith M 2006 Common leadcorrected laser ablation ICP-MS U-Pb systematics and geochronology of titanite; Chem. Geol. 227 37-52.

Swami Nath J, Ramakrishnan M and Viswanatha M N 1976 Dharwar stratigraphic model and Karnataka craton evolution; Geol. Surv. India Records 107 149-175.

Taylor S R and McLennan S M 1985 The Continental Crust: Its Composition and Evolution (Oxford: Blackwell) 312 pp.

Tiepolo M, Oberti R and Vannucci R 2002 Trace-element incorporation in titanite: Constraints from experimentally determined solid/liquid partitioning coefficients; Chem. Geol. 191 105-119.

Tucker R D, Råheim A, Krogh T E and Corfu F 1987 Uranium-lead zircon and titanite ages from the northern portion of the Western Gneiss Region, south-central Norway; Earth Planet. Sci. Lett. 81 203-211.

Ward C D, McArthur J M and Walsh J N 1992 Rare earth element behaviour during evolution and alteration of the Dartmoor granite, SW England; J. Petrol. 33 785-815.

Watson E B 1976 Two-liquid partition coefficients: Experimental data and geochemical implications; Contrib. Mineral. Petrol. 56 119-134.

Zhang L S and Schärer U 1996 Inherited Pb components in magmatic titanite and their consequences for the interpretation of $\mathrm{U}-\mathrm{Pb}$ ages; Earth Planet. Sci. Lett. 138 $57-65$. 